\title{
No More Equal: Critical Discourse of Symbolic Violence to Woman in the Television
}

\author{
Raisya Maharani Ulfah $^{1 *}$ and $A G$. Eka Wenats Wuryanta ${ }^{1}$ \\ ${ }^{1}$ Universitas Paramadina
}

\begin{abstract}
This research will explain the forms of symbolic violence against women contained in the framing of television news. This study took the case of victims of sexual crimes news named Dedeuh Alfisahrin in the period April 2015 on 4 (four) news show on TV One. The purpose of this study is to explain the ideological contestation and the dynamics of constructing news of victims of sexual crimes, symbolic forms of violence contained in the construction of news and the factors influencing the news construction process. This study uses critical discourse analysis developed by Mitchel Lazar. This study has found there are two frames of victims of sexual crimes in 4 (four) news, namely: (a) economy (b) lawmorality. These forms of symbolic violence are contained within the two forms of news framing found in this study. The symbolic forms of violence are: (a) Meaning of gender bias (b) Gender biased logic and (c) The value of moral bias. There are 3 (three) factors influencing TV One's editorial in constructing news of victims of sexual crimes: (a) Ideology of patriarchy and misogyny (b) business advantage and (c) purpose and vision of media editor.
\end{abstract}

Keywords: Mass Media, Victimized Victim, Woman, Symbolic of Violence, Gender Equality

\section{Introduction}

Women are often treated as the object of violence by media coverage, in news of rape, murder and prostitution. In the case of rape of female victims, in addition to knowing how the process of violence occurred, audiences such as directed by the media to blame the victim ${ }^{1}$. This meant that mass media are often insensitive and fulfill the rights of women victims of criminal and / or violence cases.

Often in the news on women victims of sexual crimes, the media conveyed opinions, presuppositions, judgments, blaming victims of violence within the news content. In the context of this precise news report, the television media framed victims of sexual violence and crime with a patriarchal and misogynous paradigm so that the victim is positioned as the guilty party of another's crimes against him, the main object of regulating prostitution, the moral offender, accepting the negative stigma of the sex work profession and the main commodity of prostitution business.
News Framing about women victims of crime was formed using the critical paradigm in the construction of society, namely patriarchy and misogyny. Through the paradigm, television dominated the public discourse onto one direction and without giving space for a justice-seeking view for women perspective. The dominance of discourse spaces was done subtly, using implicit meaning (vague), directing people who were exposed to information and subdominant groups (in favor of justice for women victims of crime) to accept the paradigm built by television.

Such dominance was a form of symbolic violence. Pierre Bourdieu says: Smooth and invisible and invisible violence that hides behind power relations ${ }^{2}$. Symbolic violence worked by concealing the imposition of domination to become something that is accepted as "the right thing to do". This is what then makes those who are dominated to be no objection or sincerity to be dominated and in a circle of domination.

Symbolic violence could simply be interpreted as a form of dominance of discourse using the dominant view / paradigm in society's construction by television

\footnotetext{
* Corresponding author: rai.maharani@gmail.com
} 
against non-dominant or minority circles implicitly, so that non-dominant and exposed parties are not aware that they are being led to follow such dominant views. Symbolic violence works by using views, values, dominant discourses believed by society so that people exposed to dominant discourses and victims of symbolic violence never realize that they accept violence.

The reason was that the dominant values and had been legitimized through culture, religion, education so that values and views are regarded as things that should be (nature) by society. In interpreting the context of the issue of women victims of sexual crimes, mass media including television should use the principle of balance. The principle of balance refers to using a comprehensive or appropriate perspective and perspective to frame women victims of sexual crimes.

In order to apply the principle of balance in producing news of victims of sexual crimes, media editors should use perspective in accordance with the principles of human rights of victims is one of them is justice (feminism perspective). This symbolic violence can be seen in the preaching of sexual crimes victim named Dedeuh Alfisahrin in tvOne. The purpose of this research is to explain and explain: (a) the form of news constructions formed by tvOne on news of Dedeuh's murder (b) symbolic forms of violence in narrative and news images (c) what kind of feminist equality factors influenced Dedeuh's in the news construction process in media editors (sociology and media ideology).

\section{A Discourse of Symbolic Violence on Women}

Symbolic violence is a term popularized by Pierre Bourdieu, a French thinker. According to Bourdieu, symbolic violence is a form of violence that occurs when the victim does not see and perceive it as violent, but as natural. Or in other words, symbolic violence is an invisible force. Furthermore, he said that this symbolic violence was the root of all forms of violence. Because of this symbolic violence, new forms of violence, such as psychological and physical violence, were created.

Lardellier and Jehel in Haryatmoko define violence as a principle of action based on the power to force others without consent[3]. In the violence contained retreat dominance against other parties with various forms: can be physical, verbal, moral, psychological or through images. An attitude and action can be regarded as violence if there is an element of coercion in it.

Senn in the Code, in Sunarto says in traditional discourse, academics have defined violence primarily as a physical action committed by an individual or other individual in order to cause harm to and damage to objects or persons become victims of violence[1]. Symbolic violence is not far from the aspect of discourse. Michel Foucault, sees discourse as the production of knowledge through language[4]. Foucault cleverly criticized the meaning contained behind knowledge, namely power. According to him, there is no pure and neutral knowledge. Because the real meaning of power in it. Thus, the will to know is the will to power. Bourdieu defines symbolic violence as the subtle and invisible and invisible violence that lurks behind a lame power relation. Symbolic violence works by concealing the imposition of domination to become something that is accepted as "the right thing to do". This is what then makes those who are dominated to be no objection or sincerity to be dominated and in a circle of domination[2]. Symbolic violence can be recognized by three forms, as Bordieu refers to, meaning, judgment, and signaling[2]. Three forms of Bourdieu's symbolic violence to be a blurring of meanings, refraction of logic and refraction.

\section{Media Scape in the Contestation of Masculinity and Femininity}

The issue of gender equality and justice was a long-standing problem that was still an interesting discourse in various studies. Gender inequalities still occur in many parts of the world even in our environment. Many believe that men are created more dominantly, more super than women. This is reinforced by patriarchal culture that developed almost all regions of the world. In addition to the patriarchal culture that was formed, some religious interpretations also helped strengthen the views of men were created higher degree than women.

Until now the study of gender relations has not really been completed there are still many contradictions and debates on the issue. The study of male and female relationships is an interesting study when it comes to social change. There is a fundamental question that often arises, why the roles of women seem to be only subordinate of the role of men. The role of women is considered complementary to the many roles that exist. It is men who determine what role roles men and women are supposed to perform. That men are considered to be the authorities and should dominate to be a common assumption, if there are a men who have no authority or his domination is less to women then it will be questioned "manhood". Men must be stronger and powerful is viewed as imperative otherwise it will be considered insulting to men.

Ideology affects the framing of mass media. In the context of the issue of protection of women victims of crime and sexual violence, one of the ideologies that can be used to see the context of the construction of symbolic violence is the ideology of feminism and ideology opposed to feminism, such as patriarchies and misogynies. Both types of ideology can help researchers to understand the context and causes of symbolic violence to women victims of crime and sexual violence.

Initially, feminism was a form of a women's movement that demanded equal equality between women and men. According to Stacey in Sunarto feminist theory usually suggests on a framework of knowledge that offers critical explanations for the subordination of women[1]. Critical here is meant as an explanation that does not seek to affirm and legitimize, but instead try to investigate, expose, or challenge the subordination of women. In Stacey's view, there are several key issues for understanding this oppression of women: (1) patriarchies (2) female subordination level 
(3) female category (4) implications of ideological determination of feminist theories.

\section{Methodology}

Critical discourse analysis (AWK) is an attempt or process to describe a text (social reality) that is willing or being studied by a dominant person or group whose tendency has a particular purpose to obtain what is desired. That is, in a context must be aware of the existence of interest. Therefore, the analyzes that are formed will later be influenced by the author of various factors. In addition, must be aware also that behind the discourse that there is a desired meaning and image and interests that are being fought.

Feminist CDA is a recent development under the broader branch of critical discourse analysis. Motivation for the need of a feminist CDA was that key theorists of CDA (eg Fairclough, Van Dijk) have not been interested in analysis of gender, done in the field of critical discourse analysis from a feminist perspective into a specific approach.

\section{Discussion}

The idea that refers to the ideology or culture of patriarchy and misogyny is a very dominant discourse of mastering public sphere in Indonesia. Based on Pierre Bourdieu's theory, when there is an attempt of domination or mastery included in the context of discourse in the media, to make the sub-dominant group agree, obeys the dominant discourse or idea, that's where symbolic violence occurs.

Symbolic violence was violence that operated in the realm of the subconscious of the individual, so that the perpetrators of symbolic violence often do not realize that his attitude or action is already a violation for others. In the context of reporting Dedeuh, researchers found forms of symbolic violence carried out by the media TVOne victims through news content tvOne.

The findings of symbolic violence were confirmed to the editor of the program Apa Kabar Indonesia Malam, Unveiling the Daylight and Daylight. The presence of symbolic violence by the three editors of TVOne to the victims could be seen from their attitudes and views in the results of interviews with researchers. These attitudes and views reflect the existence of misogynous ideology and patriarchy based on the principle and definition of the concept has a negative tendency and repressive nature of women.

Using the misogynous and patriarchal perspective of putting the Dedeuh murder case into the news, it proves to be a form of public discourse using the ideas and ideas of misogyny and patriarchy to lead the public and sub-dominant groups (in this case Dedeuh and the group of sex workers) to follow and agree on the idea the.

The dominance of discourse using ideas and ideas derived from the ideology of misogyny and patriarchy is symbolic violence because it forces subtly or leads the public and sub-dominant groups to adhere to the idea of the idea without them knowing it. Symbolic violence in the mass media is also detrimental to women victims because of the idea that it was built impartially on the protection and right of justice for victims of crime. The division of roles by sex is a cultural history that can be said to be the oldest tradition. The structure of body was decisive humans to get the role in the certain situations. In general, the initial roles are differentiated by sex. The role of the agreed role as the public role will be more dominated by men and the roles agreed upon as the domestic role will be mostly done by women. It has become an "agreed" general "deal". Social construction that legitimized by the roles that have been attached closely to men and women and a form of ratification of masculine domination[2]. Public spaces in some cases are not male domains; the market is one such example. But if you look at the goods sold by women mostly are goods that support domestic needs are "tight" with women.

\section{Conclusion}

This research sought to find news construction and a form of symbolic violence in the news of women victims of crime that were built by tvOne. This research was conducted by analyzing 4 (four) news of Dedeuh Alfisahrin's murder theme from 3 (three) tvOne broadcast program in April 2015 period. The researcher chose tvOne as the research subject because tvOne is one television station that gives big and deep space to the issue of murder Dedeuh compared to other television stations.

The second reason, researchers found the Dedeuh news show on tvOne had a strong symbolic violence compared to similar themes on other television stations. Third, tvOne is one of the leading public television news stations among other news stations. TvOne also has great power to influence public opinion and discourse given the amount of audience that TVOne has.

Researchers assume that the role of TVOne affect the opinions and mindset of society, then when there is a mistake in news products that dibabngun by editor, it can be bad for the audience or audience who listen to the news broadcast. There are examples with news bias due to the owner's interests with the media. so that it is possible to report such as the natural environment, social environment will experience refraction in the delivery to the public. Moreover, in the context of this research, there is a potential for understanding the news of victims of crime to the public through the construction of news stories that contain symbolic violence.

Researchers agreed with the theory of feminism and the principles of journalistic code of ethics that occupied victims of criminal and sexual violence as parties that must be protected and get support from the mass media. Support here means that news content must meet the interests of victims 'protection and victims' right of justice. Victims of crimes in the context of 
Dedeuh, deserve justice from various parties, especially the community.

The mass media as a community tongue and reality should be able to positively criminalize crime victims, balanced fact substances (not cornering victims), sensitive to gender, protecting the privacy rights of victims in their news content. Victims are not eligible for re-victimization (double victimization) in the media content, unfeasible to be exploited for industrial gain and unfairly cornered due to unfair ideology of women's identity (misogynies and patriarchies).

\section{References}

1. Sunarto,Televisi, Kekerasan \& Perempuan , Kompas Media Nusantara, Jakarta (2009).

2. P. Bourdieu, Dominasi Maskulin, Jalasutra, Yogyakarta (2010).

3. Haryatmoko, Dominasi Penuh Muslihat (Akar Kekerasan dan diskriminasi), Gramedia, Jakarta (2010).

4. M. Foucault, The Archeology of Knowledge, Tavistock Publications, London (1972).

5. C. Weendon, Feminist Practice and Poststructuralist Theory, Second edition, Blackwell Publishing, Oxford (1997).
6. G. Ritzer and D.J. Goodman, Teori Sosiologi Modern, Kencana, Jakarta (2005).

7. Rustiansyah, Patron-Klien Dikalangan Petani Desa Kebon Rojo, Universitas Air Langga, Surabaya (2011).

8. J. Sunderland and L. Litosseliti, Gender Identity and Discourse Analysis. Theoretical and Empirical Considerations, in L. Litosseliti (ed.) Gender Identity and Discourse Analysis, Philadelphia: John Benjamins, 1-39 (2002).

9. N. Fairclough, Critical Discourse Analysis, Longman, London (1995).

10. S.I.H. Saptiawan, Gender dan Inferioritas Perempuan (Praktik Kritik Sastra Feminis), Pustaka Pelajar, Yogyakarta (2010).

11. V. Flanagan, Cross-Dressing and the Gendered Body in Children's Literature, Doctoral dissertation, Macquarie University, Sydney (2005).

12. Y. S. Suryandaru, (ed), Potret Kesadaran Gender Orang Media, Laporan Penelitian, Pusat Studi Wanita Universitas Airlangga dan Kementrian Pemberdayaan Perempuan RI (2002).

13. Z. A. Baso, T. D. Aries, S. Haerani, and A. Rahman, Kekerasan Terhadap Perempuan, (2002). 